\title{
A Short Review on Biobutanol, a Second Generation Biofuel Production from Lignocellulosic Biomass
}

\author{
Manoj Kumar Mahapatra and Arvind Kumar
}

\begin{abstract}
Acute energy crisis and the fast depletion of fossil fuel reserves globally has aroused the research interest of scientists all over the world to find out sustainable technologies for biofuel production. Although in the modern era several biofuels such as bioethanol, biodiesel, etc. exists, however, the research focus is shifting towards biobutanol because of its astonishing potential for replacing gasoline as a solo fuel in gasoline internal combustion engines without revamping them, and hence it has got the synonym as biogasoline. Moreover, biobutanol is superior to bioethanol in terms of energy content, moisture affinity and blending capacities. Biobutanol is produced from lignocellulosic biomasses which are not only renewable but also abundantly found either at a cheaper price or even free. Most importantly these biomasses do not compete with food crop biomasses. Biobutanol production is essentially based on anaerobic (ABE) fermentation of lignocellulosic biomasses by solventogenic Clostridium acetobutylicum bacteria. This article will represent a brief review on biobutanol production from lignocellulosic biomasses by ABE (acetone-butanol-ethanol) fermentation process.
\end{abstract}

Index Terms-Biobutanol, biogasoline, ABE fermentation, clostridium acetobutylicum, lignocellulosic biomass.

\section{INTRODUCTION}

Brisk technological advancement globally has raised the demand of conventional fuels like never before. Although they have the pros of being major energy suppliers, globally about $85 \%$ of total energy demand is quenched by conventional fuels but are not totally free from certain cons namely (1) quantitative limitation of their sources and hence they are going to be exhausted in coming years, (2) devastating environmental impacts due to extensive usage. These two limitations have provoked scientists to look for sustainable technologies to replace conventional fuels with renewable and eco-friendly energy sources, in the course of which biomass-derived energy appeared as the most attractive options available [1]. Schematic representation of biofuel production from biomass is given in Fig. 1.

Now-a-days there are several buzzwords floating in the biofuel research field such as biodiesel, bioethanol and biobutanol. However, the later one is gaining much attention in the course of time because its' superior potential of catering the needs as an excellent sustainable biofuel as well as an important industrial solvent cum precursor. Some of the industrial applications of butanol are described below.

Manuscript received October 9, 2015; revised December 29, 2015.

Manoj Kumar Mahapatra and Arvind Kumar are with the Department of Chemical Engineering, National Institute of Technology, Rourkela, 769008, India (e-mail: 512ch1013@nitrkl.ac.in, arvindkumar@nitrkl.ac.in).

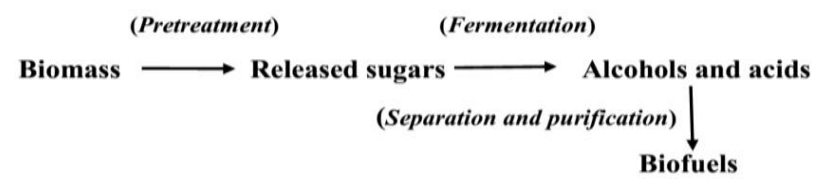

Fig. 1. Flow diagram of biofuel production from biomass [2].

Butanol is used as a:

- Solvent for rubber production, quick-drying lacquer to exhibit an excellent surface finish and in dye industry such as printing ink industry.

- Extractant in pharmaceuticals for drugs, natural substrates like antibiotics, hormones and vitamins etc.

- Supplement in polishes and cleaners used for domestic as well as industrial cleansing.

- De-icing fluid in textile industry for solubilization and also for gasoline in cold countries.

- Eluent in thin layer and paper chromatography.

- Precursor for the production of acrylic esters, glycol ethers, butyl acetate, butyl amines.

Apart from the above striking industrial applications butanol has been proved to be an excellent biofuel, since it can be directly used in gasoline driven engines without modifying them, moreover it has superiority in terms of energy density and heat of vaporization over ethanol in order to qualify as an excellent biofuel [3]. Table I describes different fuel properties of gasoline, butanol, ethanol and methanol.

TABLE I: COMPARISON OF FUEL CHARACTERISTICS OF GASOLINE AND

\begin{tabular}{cccccc}
\multicolumn{7}{c}{ BIOALCOHOLS [4] } \\
\hline Fuel & $\begin{array}{c}\text { ED, } \\
(\mathrm{MJ} / \mathrm{L})\end{array}$ & $\begin{array}{c}\mathrm{A} / \mathrm{F} \\
\text { ratio }\end{array}$ & $\begin{array}{c}\mathrm{HV}, \\
(\mathrm{MJ} / \mathrm{Kg})\end{array}$ & ROT & MOT \\
\hline Gasoline & 32.0 & 14.6 & 0.36 & $91-99$ & $81-89$ \\
Butanol & 29.2 & 11.2 & 0.43 & 96 & 78 \\
Ethanol & 19.6 & 9.0 & 0.92 & 130 & 96 \\
Methanol & 16.0 & 6.5 & 1.20 & 136 & 104 \\
\hline
\end{tabular}

Biobutanol production is essentially based on fermentation process by solventogenic Clostridium sp. bacteria (Weizmann organism) since they possesses the ability to utilize simple and complex sugars, like pentose, hexose, etc. Moreover to make the production process economical extracted sugars from pretreatment of lignocellulosic biomass are used as substrates for fermentation. The solventogenic fermentation process is often limited by certain factors namely substrate inhibition, butanol toxicity in the medium, slow growth, and hence, lower cell density. Apart from these limitations, biobutanol yield is also gets reduced because of production of other end products such as acetone and ethanol. To tackle these problems researchers have developed microbial strains capable with improved biobutanol yield and tolerance by genetic engineering. 
Feedstock or raw materials are one of the most vital components for fermentation process. During Weizmann process (for $\mathrm{ABE}$ fermentation) era, corn was used as primary substrate. On the contrary, molasses was used as the substrate for industrial scale $\mathrm{ABE}$ fermentation, where $C$. acetobutylicum was used as the agent for fermentation process in both the cases. Literature shows that several starchy substrates such as sweet potato, cassava, wheat starch, potato waste and low grade potatoes, food industry wastes such as cheese whey, apple pomace, palm oil mill effluent, soy molasses, etc. have been used as raw materials for $\mathrm{ABE}$ fermentation [5]. However, raw material cost has a direct impact on the economy of the butanol production process. Hence, the option for raw material choice was shifted to lignocellulosic biomasses such as agricultural residues like rice straw, wheat straw, corn stover, waste wood, etc. Depending upon the usage of raw materials, biobutanol is also classified in to different generations. The title of this paper says second generation biofuel, which signifies non-food biomasses such as lignocellulosic biomasses are used for fermentation process.

\section{A COMPENDIUM OF BIOBUTANOL PRODUCTION FROM BIOMASS}

Synergistic action of solventogenic Clostridium sp. and biocatalysts (enzymes) upon biomass during the course of $\mathrm{ABE}$ fermentation process leads to production of some of the most notable solvents and biofuels namely acetone, butanol and ethanol. The entire course of biofuel production has been represented in a schematic flow diagram in Fig. 1. As we have already mentioned that biofuel research has gained pace in the search of an economical, renewable fuel source which will answer to gradual depletion of fossil fuels and their adverse environmental impacts [2]. However, biofuels also come up with benefits and limitations in terms of their environmental and economic impacts. These facts are summarized in Table II.

TABLE II: ENVIRONMENTAL AND ECONOMIC IMPORTANCE OF BIOFUELS [1]

\begin{tabular}{ll}
\hline Environmental impacts & Economic impacts \\
\hline Pros & Pros \\
\hline Lesser need of conventional fossil & $\begin{array}{l}\text { Relatively inexpensive leading to } \\
\text { price stability }\end{array}$ \\
$\begin{array}{l}\text { Reduction in GHG, toxic chemicals } \\
\text { and smog }\end{array}$ & $\begin{array}{l}\text { Employment opportunities in } \\
\text { rural areas }\end{array}$ \\
Lesser need for landfill sites & $\begin{array}{l}\text { Usage of underutilized and cheap } \\
\text { biomass }\end{array}$ \\
\hline Cons & Cons \\
\hline Reduced biodiversity due to & Cost towards technology \\
cultivation of favoured crop & invention and maintenance \\
Chances of ecosystem disbalance & Additional cost in storage and \\
due to GEMs and desired crops & pretreatment of biomass \\
Possibility of air and soil pollution & \\
due to use of fertilizers and & \\
pesticides & \\
\hline
\end{tabular}

In the course of biofuel especially biobutanol production, the most striking and important step is separation process. This step is crucial because not only it saves resources and time by recovering products in time but also increases yield by reducing the chances of solvent toxicity towards microbes. Now-a-days several separation techniques such as adsorption, gas stripping, liquid-liquid extraction (LLE), perstraction, pervaporation, and reverse osmosis (RO) are in use especially for butanol recovery from fermentation broth. Table III embodies a collection of biobutanol production from different substrates [6].

TABLE III: BIOBUTANOL PRODUCTION BY ABE FERMENTATION [7]

\begin{tabular}{|c|c|c|c|c|}
\hline Bacteria & Strain no. & Substrate & $\begin{array}{l}\text { Time } \\
\operatorname{span}(h)\end{array}$ & $\begin{array}{l}\mathrm{BuOH} \\
\text { yield } \\
(\mathrm{g} / \mathrm{L})\end{array}$ \\
\hline C. beijerinckii & BA101 & $\begin{array}{l}\text { Soy } \\
\text { molasses }\end{array}$ & 96 & 8 \\
\hline C. acetobutylicum & IFP904 & $\begin{array}{l}\text { Jerusalem } \\
\text { artichoke }\end{array}$ & 33 & 14.8 \\
\hline C. acetobutylicum & P262 & $\begin{array}{l}\text { Sago } \\
\text { starch }\end{array}$ & 75 & 16 \\
\hline C. acetobutylicum & ATCC 824 & $\begin{array}{l}\text { domestic } \\
\text { organic } \\
\text { waste }\end{array}$ & 120 & 3 \\
\hline C. beijerinckii & P260 & $\begin{array}{l}\text { Wheat } \\
\text { straw }\end{array}$ & 42 & 12 \\
\hline C. beijerinckii & P260 & $\begin{array}{l}\text { Barley } \\
\text { straw }\end{array}$ & 68 & 18 \\
\hline C. acetobutylicum & $\begin{array}{l}\text { ATCC } \\
4259\end{array}$ & $\begin{array}{l}\text { Glycerol } \\
\text { and } \\
\text { glucose }\end{array}$ & 20 & 8.6 \\
\hline $\begin{array}{l}\text { C. } \\
\text { saccharoperbutylac } \\
\text { etonicum }\end{array}$ & $\mathrm{N} 1-4$ & $\begin{array}{l}\text { algal } \\
\text { biomass }\end{array}$ & 96 & 2.3 \\
\hline
\end{tabular}

\section{BIOMASS FOR BIOBUTANOL PRODUCTION}

Presently the biomass derived energy supply (approximately $50 \mathrm{EJ}$ ) contributes to only $10 \%$ of global annual energy needs and the values are rising each day. It is estimated that by 2050 biomass derived energy supply will contribute to about 1500 EJ of energy supply. Biofuels including biobutanol are categorized in to different generations depending upon the biomass used. First, second and third generation biobutanol are produced from food crops, non-food crops and microalgae etc respectively [1], [3]. Principal characteristic features of globally available different biomasses for biobutanol production are mentioned in Table IV.

First generation biomasses are edible feedstocks like sugarcane, wheat and corn which inherently have high sugar/starch content. Although the surplus part of these biomasses is utilized for biofuel production but with an increase in biofuel demand, threat towards food scarcity will arise. Biodiesel and bioethanol are some of the outcomes of these biomasses. Second-generation feedstocks comprises of lignocellulosic biomass and crop waste residues from agricultural and forestry activities, which usually have associated disposal problem [7].

Usage of these biomasses came in to action because of the exponential increase in renewable energy demand Biobutanol is one of the primary outputs of these biomasses. Photosynthetic bacteria and algae are considered as third-generation biomasses. These are used because of their high oil/lipid, carbohydrate, or protein contents. They have 
the advantage over other two categories of biomasses since these do not need any cultivable land and assorted farming inputs, more over they have high lipid content approximately $20-40 \%$ of their dry weight. Currently technological immaturity is the primary constraint in biofuel production from this group of biomass, but it is expected that it will be a main stream process in upcoming years [1].

TABLE IV: PRINCIPAL CHARACTERISTICS OF BIOMASSES AVAILABLE [1]

\begin{tabular}{llll}
\hline Biomass & Advantage & $\begin{array}{l}\text { Status of } \\
\text { assorted } \\
\text { technologies }\end{array}$ & Shortcomings \\
\hline $\begin{array}{l}\text { First generation } \\
\text { (food crops) }\end{array}$ & $\begin{array}{l}\text { High energy } \\
\text { content }\end{array}$ & $\begin{array}{l}\text { Well versed and } \\
\text { tested over time }\end{array}$ & $\begin{array}{l}\text { Cultivable } \\
\text { lands are } \\
\text { needed at large }\end{array}$ \\
$\begin{array}{l}\text { Second } \\
\text { generation } \\
\text { (non-food }\end{array}$ & $\begin{array}{l}\text { No competition } \\
\text { with food crops }\end{array}$ & $\begin{array}{l}\text { Young and } \\
\text { amendments are }\end{array}$ & $\begin{array}{l}\text { Tedious and } \\
\text { costly }\end{array}$ \\
$\begin{array}{l}\text { Third } \\
\text { generation } \\
\text { (microalgae) }\end{array}$ & $\begin{array}{l}\text { No need for } \\
\text { farming and }\end{array}$ & Immature & Pretty low \\
& cultivable land & & yield \\
\hline
\end{tabular}

\section{MicRobes For BiobutANOL PRODUCTION}

Solventogenic bacteria Clostridium sp. is the causative organism behind biobutanol production via $\mathrm{ABE}$ fermentation process. Genus Clostridia embodies a wide variety of biobutanol producing bacteria out of them, $C$. acetobutylicum, $\quad$ C. beijerinckii, $C$. saccaroperbutylacetonicum, and C. saccharoacetobutylicum have exhibited capability for butanol synthesis accompanied by higher yields. The Weizmann organism C. acetobutylicum, which has typical bacterial characteristics such as being bacillus, sporulating, gram-positive and strictly anaerobe, was the only bacterium employed in industrial fermentation for production of acetone and butanol during last century.

TABLE V: Mutagenesis Practice on Microbes Yielding Butanol [3],

\begin{tabular}{|c|c|c|c|}
\hline Naive strain & Mutagen & $\begin{array}{l}\text { Mutant } \\
\text { strain }\end{array}$ & Outcomes \\
\hline $\begin{array}{l}\text { C. } \\
\text { acetobutylicum } \\
\text { ATCC } 824\end{array}$ & Butanol & SA-1 & $\begin{array}{l}121 \% \text { higher } \\
\text { butanol tolerance }\end{array}$ \\
\hline $\begin{array}{l}\text { C. } \\
\text { acetobutylicum } \\
\text { PTCC-23 }\end{array}$ & $\begin{array}{l}\text { UV exposure, } \\
\text { methylnitronitrosog } \\
\text { uanidine } \\
\text { and ethyl methane } \\
\text { sulphonate }\end{array}$ & $\begin{array}{c}\text { MEMS- } \\
7\end{array}$ & $\begin{array}{l}\text { Yield is enhanced } \\
\text { by } 20 \%\end{array}$ \\
\hline $\begin{array}{l}\text { C. } \\
\text { acetobutylicum } \\
\text { ATCC } 824\end{array}$ & $\begin{array}{l}\text { Methylnitronitrosog } \\
\text { uanidine and } \\
\text { 2-deoxyglucose }\end{array}$ & $\begin{array}{l}\text { BA101, } \\
\text { BA-105 }\end{array}$ & $\begin{array}{l}\text { Amylolytic } \\
\text { activity increased } \\
\text { by } 82 \% \text { and } 25 \%\end{array}$ \\
\hline E. coli JCL16 & 4-aza-D,L-leucine & $\begin{array}{l}\text { AL-1, } \\
\text { AL-2 }\end{array}$ & $\begin{array}{l}\text { Yield enhanced by } \\
33 \%\end{array}$ \\
\hline
\end{tabular}

However, with the advancement of technologies like DNA fingerprinting and RNA sequencing, the butanol producing capability of some other bacteria from Clostridium genus were also unveiled. These bacteria are $C$. beijerinckii, $C$. saccharoperbutylacetonicum and $C$. saccharobutylicum. However the bacterial strain selection is not absolutely random rather is based upon certain factors such as type of biomass, productivity target, nutrient requirement, product toxicity tolerance, and resistance from bacteriophage [3]. The capabilities in terms of product toxicity tolerance and yield of these microbes have been enhanced by mutagenesis. Mutagenesis can be brought by physical as well as chemical means like exposure to radiations, acclimatization of microbes with certain chemicals respectively. UV exposure, butanol, N-methyl-N-nitro-N-nitrosoguanidine (MNNG) and ethyl methane sulphonate are some of the notable mutagens for enhancing the capabilities of Clostridium sp. [8], [9]. Table V enlists mutagenesis process implemented upon microbes and their results.

\section{ABE FERMENTATION PROCESS}

In the fermentation industry $\mathrm{ABE}$ fermentation holds the distinction of being second largest process next to ethanol fermentation. However in ABE fermentation process, instead of just one, three different products are produced which makes it more attractive as compared to others in terms of different product yield. Like other fermentation processes, $\mathrm{ABE}$ fermentation is also distinguished in to 3 different types namely batch, fed-batch and continuous mode of fermentation process. Again in continuous mode of fermentation, three different strategies namely free cell, immobilized cell, and cell recycles are also employed [3].

Metabolic activities of microbes play the decisive role in the fermentation process. ABE fermentation process is biphasic in nature containing both acidogenesis and solventogenesis phases. Fig. 2 represents metabolic pathway of $\mathrm{ABE}$ fermentation process and its components i.e. enzymes and products. The metabolic pathways in some of the Clostridium sp. are all alike such as those of $C$. acetobutylicum and $C$. beijerinckii are alike. Butanol, acetone, ethanol, acetic acid, butyric acid, $\mathrm{CO}_{2}$, and $\mathrm{H}_{2}$ are the end products from metabolic pathway of Clostridium sp. during $\mathrm{ABE}$ fermentation process [10].

\section{RECOVERY OF BIOBUTANOL FROM FERMENTATION BROTH}

This is the most expensive part of biobutanol fermentation process, hence is a decisive factor for production. Several recovery techniques are in action today starting from age old distillation technology, adsorption, liquid-liquid extraction, gas stripping and membrane based methods like reverse osmosis, perstraction, pervaporation, etc. Amidst the existence of all these techniques, still there is no clear answer about which technique is the best [4], [11]. A brief summary of above techniques is portrayed in Table VI.

\begin{tabular}{|c|c|c|c|}
\hline Method & Basic Principle & $\begin{array}{l}\text { Major } \\
\text { advantages }\end{array}$ & $\begin{array}{l}\text { Major } \\
\text { drawbacks }\end{array}$ \\
\hline Gas stripping & Gas purging & $\begin{array}{ll}\begin{array}{l}\text { Simple, } \\
\text { clogging }\end{array} & \text { less }\end{array}$ & $\begin{array}{l}\text { Incomplete } \\
\text { removal }\end{array}$ \\
\hline $\begin{array}{l}\text { Liquid-liquid } \\
\text { extraction }\end{array}$ & $\begin{array}{l}\text { Organic solvent } \\
\text { contact }\end{array}$ & High capacity & Expensive \\
\hline $\begin{array}{l}\text { Membrane } \\
\text { evaporation }\end{array}$ & $\begin{array}{l}\text { Selective } \\
\text { diffusion }\end{array}$ & $\begin{array}{l}\text { Smaller } \\
\text { membrane need }\end{array}$ & $\begin{array}{l}\text { Clogging } \\
\text { occurs }\end{array}$ \\
\hline Perstraction & $\begin{array}{l}\text { Membrane and } \\
\text { solvent }\end{array}$ & High selectivity & $\begin{array}{l}\text { Large } \\
\text { membrane area }\end{array}$ \\
\hline Adsorption & $\begin{array}{l}\text { Hydrophobic } \\
\text { adsorbents }\end{array}$ & $\begin{array}{l}\text { High uptake } \\
\text { capacity }\end{array}$ & $\begin{array}{l}\text { Desorption is } \\
\text { tedious }\end{array}$ \\
\hline
\end{tabular}




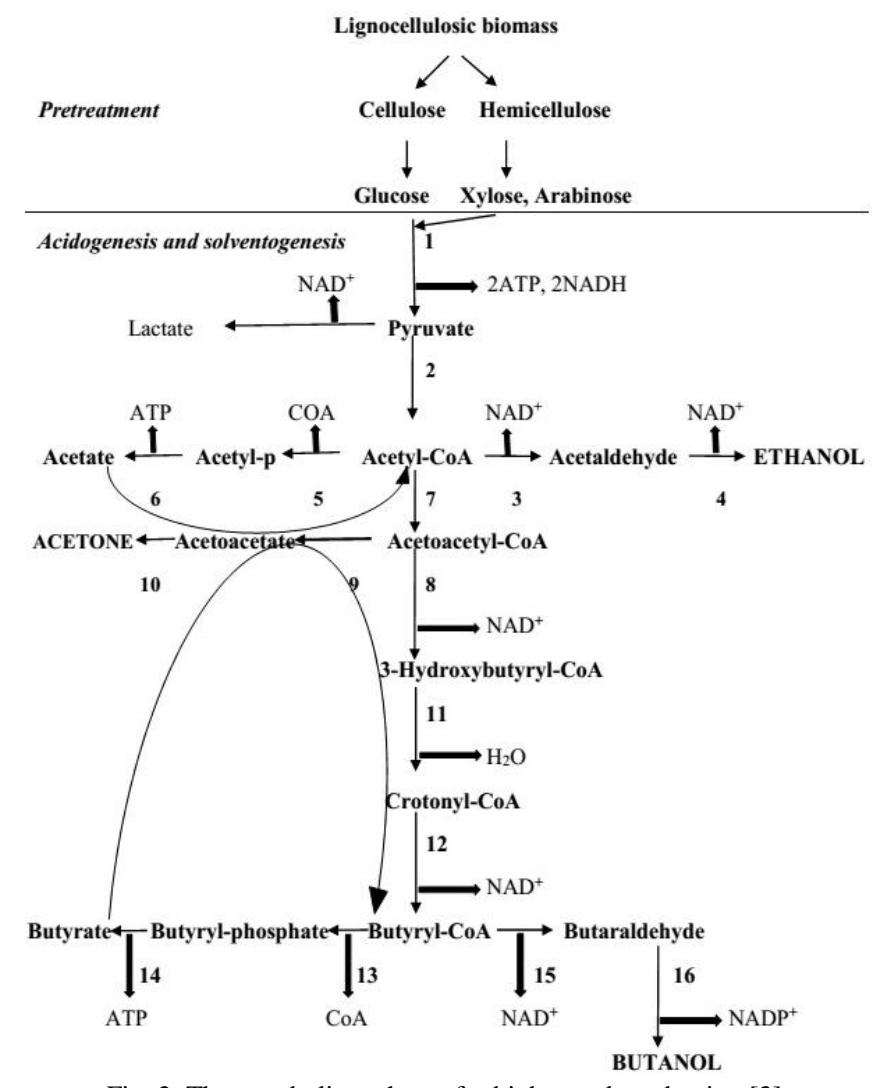

Fig. 2. The metabolic pathway for biobutanol production [3].

The numbers depicts enzymes and are as follows: (1) Enzymes of glycolysis process; (2) Pyruvate ferredoxinoxidoreductase; (3) Acetaldehyde dehydrogenase; (4) Ethanol dehydrogenase; (5) Phosphate acetyltransferase (phosphotransacettylase); (6) Acetate kinase; (7) Thiolase (acetyl-CoA acetyltransferase); (8) 3-hydroxybutyryl-CoA dehydrogenase; (9) Acetoacetyl-CoA: acetate/butyrate: CoA-transferase; (10) Acetoacetate decarboxylase; (11) Crotonase; (12) Butyryl-CoA dehydrogenase; (13) Phosphate butyltransferase (phosphotransbutyrylase); (14) Butyrate kinase; (15) Butyraldehyde dehydrogenase; (16) Butanol dehydrogenase.

\section{CONCLUSION}

Biobutanol, in recent years, is being considered as one of the most potent alternatives to conventional gasoline. Sustainable production of butanol using biomass as raw material has considerably lesser carbon foot print on the environment. Considering renewable nature of biomass, biobutanol is a lucrative biofuel which has all the properties of future alternative fuel. However, the upstream and downstream technologies like highly efficient microbial consortium and efficient recovery technologies, respectively, need to be improvised so as to make biobutanol a truly global fuel of the future.

\section{NOMENCLATURE}

$\mathrm{ED}=$ Energy density, $\mathrm{A} / \mathrm{F}=$ Air to fuel ratio, $\mathrm{HV}=$ Heat of vaporization, $\mathrm{ROT}=$ Research octane testing, MOT $=$ Motor octane testing, $\mathrm{ABE}=$ Acetone, butanol and ethanol, $\mathrm{MJ} / \mathrm{L}=$ mega joules per liter, EJ= Exa Joule, LLE $=$ Liquid-liquid extraction, $\mathrm{RO}=$ Reverse osmosis, GEM= Genetically engineered microbes, $\mathrm{BuOH}=\mathrm{Butanol}$

\section{ACKNOWLEDGMENT}

Manoj Kumar Mahapatra wishes to acknowledge his supervisor Prof. Arvind Kumar for his guidance during manuscript preparation. The authors acknowledge, ministry of HRD, govt. of India and Director, NIT, Rourkela, for providing financial support and assorted facilities needed for carrying out the research work.

\section{REFERENCES}

[1] K. Srirangan, L. Akawi, M. M. Young, and P. Chou, "Towards sustainable production of clean energy carriers from biomass resources," Applied Energy, vol. 100, pp. 172-186, May 2012.

[2] P. Kumar, D. M. Barrett, M. J. Delwiche, and P. Stroeve, "Methods for pretreatment of lignocellulosic biomass for efficient hydrolysis and biofuel production," Industrial and Engineering Chemistry Research, vol. 48, pp. 3713-3729, March 2009.

[3] M. Kumar and K. Gayen, "Developments in biobutanol production: New insights,” Applied Energy, vol. 88, pp. 1999-2012, January 2011.

[4] J. Cheng, Biomass to Renewable Energy Processes, 1st ed. New York: CRC Press, 2010, ch. 8, p. 272.

[5] D. T. Jones and D. R. Woods, "Acetone-butanol fermentation revisited," Microbiology Review, vol. 50, no. 4, pp. 484-524, December 1986.

[6] H-J. Huang, S. Ramaswamy, and Y. Liu, "Separation and purification of biobutanol during bioconversion of biomass," Separation and Purification Technology, vol. 132, pp. 513-540, August 2014.

[7] Y-S. Jang, A. Malaviya, C. Cho, J. Lee, and S. Lee, "Butanol production from renewable biomass by clostridia," Bioresource Technology, vol. 123, pp. 653-663, July 2012.

[8] J. Zheng, Y. Tashiro, Q. Wang, and K. Sonomoto, "Recent advances to improve fermentative butanol production: Genetic engineering and fermentation technology," Journal Bioscience and Bioengineering, vol. 119, no. 1, pp. 1-9, July 2014.

[9] Q. Syed, M. Nadeem, and R. Nelofer, "Enhanced butanol production by mutant strains of Clostridium acetobutylicum in molasses medium," Turkish Journal of Biochemistry, vol. 33, no. 1, pp. 25-30, April 2008.

[10] Y. N. Zheng, L. Z. Li, M. Xian, Y. J. Ma, J. M. Yang, and X. Xu, "Problems with the microbial production of butanol," Journal of Industrial Microbiology and Biotechnology, vol. 36, pp. 1127-1138, September 2009

[11] N. Abdehagh, F. H. Tezel, and J. Thibault, "Separation techniques in butanol production: Challenges and developments," Biomass and Bioenergy, vol. 60, pp. 222-246, November 2014.

[12] P. Durre, "New insights and novel developments in clostridial acetone/butanol/isopropanol fermentation," Applied Microbiology and Biotechnology, vol. 49, pp. 639-648, January 1998.

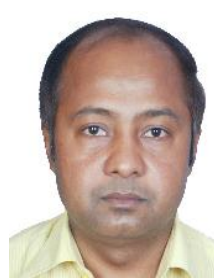

Arvind Kumar is currently serving as an assistant professor in the Department of Chemical Engineering, National Institute of Technology (NIT), Rourkela, India. He obtained his doctoral degree in chemical engineering from IIT Roorkee in 2008. Prior to his appointment at Rourkela, Dr. Arvind served at Carbon Technology Unit, National Physical Laboratory, New Delhi, India. His major interests are in industrial safety $\&$ pollution abatement, renewable energy and petroleum refining process.

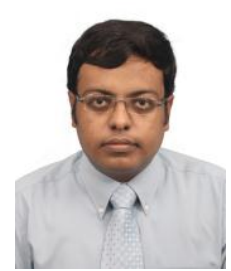

Manoj Kumar Mahapatra is a Ph.D. student at the Department of Chemical Engineering, National Institute of Technology, Rourkela, Odisha, India. His advisor is Prof. Arvind Kumar. He received his masters' degree in chemical engineering from the same institute. His research interests are renewable energy and environmental engineering. 